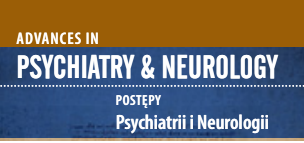

Correspondence to/Adres do korespondencji:

Department of Psychiatry

Medical University of Warsaw

27 Nowowiejska St.

00-665 Warsaw, Poland

e-mail: karolina_sapota@poczta.fm

Submitted/Otrzymano: 16.06 .2021

Accepted/Przyjęto do druku: 06.09.2021

\section{Pulmonary embolism - a considerable clinical challenge in psychiatry. Case reports}

\author{
Zatorowość płucna - duży problem \\ kliniczny w psychiatrii. Opisy przypadków
}

\author{
Karolina Sapota-Zaręba, Tadeusz Nasierowski
}

Department of Psychiatry, Medical University of Warsaw, Poland

\begin{abstract}
Purpose: Pulmonary embolism (PE) is the most serious clinical manifestation of venous thromboembolism (VTE) and a common cause of death in psychiatric patients. Patients diagnosed with mental illness have additional thromboembolic risk factors. These factors are not included in scores used to assess VTE risk. The goal of this elaboration is to take notice of the increased thromboembolic risk in psychiatric patients, with a particular focus on patients with catatonic symptoms.

Case description: Two cases of young men with catatonic symptoms who suffered from cardiac arrest during psychiatric hospitalization are reported on. Autopsy showed pulmonary embolism as the main cause of death. Based on the Padua Prediction Score the two patients had no indications for thromboprophylaxis. Both men were mostly treated with olanzapine.

Comment: PE should be always taken into account in differential diagnosis, even if patients do not present with its typical risk factors.
\end{abstract}

Key words: olanzapine, pulmonary embolism, catatonia, venous thromboembolism.

\title{
Streszczenie
}

Cel: Zatorowość płucna (ZP) jest najpoważniejszą manifestacją kliniczną żylnej choroby zakrzepowo-zatorowej (ŻChZZ) oraz częstą przyczyną zgonów w populacji pacjentów psychiatrycznych. U pacjentów z rozpoznaniem choroby psychicznej występują dodatkowe czynniki ryzyka zakrzepowo-zatorowego. Czynniki te nie są uwzględniane w skalach oceniających ryzyko ŻChZZ. Celem pracy jest zwrócenie uwagi na zwiększone ryzyko zakrzepowo-zatorowe u pacjentów hospitalizowanych psychiatrycznie, ze szczególnym uwzględnieniem chorych z objawami katatonicznymi.

Opis przypadku: Opisano dwa przypadki młodych mężczyzn z objawami katatonicznymi, u których w trakcie hospitalizacji psychiatrycznej doszło do nagłego zatrzymania krążenia. W badaniach sekcyjnych wskazano ZP jako główną przyczynę zgonu. U obu pacjentów na podstawie Skali Padewskiej nie stwierdzono wskazań do wdrożenia profilaktyki przeciwzakrzepowej. W obu przypadkach głównym stosowanym lekiem była olanzapina.

Komentarz: Zatorowość płucna powinna być zawsze brana pod uwagę w diagnostyce różnicowej, nawet jeśli u pacjentów nie ma typowych czynników ryzyka jej wystąpienia.

Słowa kluczowe: olanzapina, zatorowość płucna, katatonia, żylna choroba zakrzepowo-zatorowa.

\section{PURPOSE}

Pulmonary embolism (PE) and deep vein thrombosis (DVT) are components of venous thromboembolism (VTE), which overall is the third most common cardiovascular disease. $\mathrm{PE}$ is the most severe clinical manifestation of VTE [1]. This condition is also a common cause of death in psychiatry [2]. Patients diagnosed with mental illness have additional thromboembolic risk factors that are not included in scores used to assess VTE risk. Furthermore, mental illness is usually not listed as a risk factor in studies on this disease. Increased thromboembolic risk in psychiatric patients is associated both with their condition and psychotropic medication. It is often difficult to make contact with patients admitted to psychiatric units, in particular before appropriate treatment is initi- 
ated. Consequently, history-taking may also be limited. Patients with an acute episode of mental illness may have difficulties in expressing their symptoms. Some patients refuse to be diagnosed (e.g. to have their blood drawn or an ECG performed), e.g. because of psychosis.

Two case reports of patients with fatal PE during psychiatric hospitalization are presented below. The goal of this elaboration is to take notice of increased thromboembolic risk in psychiatric patients, with a particular focus on patients with catatonic symptoms.

\section{CASE REPORTS}

\section{Case 1}

A 34-year old patient, repeatedly hospitalized in a psychiatric unit and diagnosed with paranoid schizophrenia, was admitted to the hospital with a referral from the internal medicine ward. He was bleeding from the upper gastrointestinal tract. Additionally, the patient was diagnosed with grade IV oesophagitis with ulcers according to the Los Angeles classification, acute haemorrhagic gastritis, Helicobacter pylori infection, dehydration with electrolyte disturbances (hypokalaemia) and undefined liver failure. During the month prior to admission to the psychiatric ward the patient was hospitalized three times in a general ward, because his somatic condition deteriorated. Each time after he was discharged, he failed to comply with instructions and did not take prescribed medications. During his last hospitalization at the internal medicine ward, he had an episode of upper gastrointestinal bleeding. Therapeutic endoscopy was conducted to maintain vital functions. The procedure was performed under general anaesthesia because the patient was agitated, behaved aggressively and did not cooperate. In addition, he received 1 unit of fresh-frozen plasma. In the ward the patient was agitated, and pulled out his intravenous line. He had to be placed in four-point restraints (it is not known for how long he was immobilised). The patient refused to take medications and attend follow-ups. Contact with the patient was difficult: he did not answer questions but only gesticulated. His behaviour suggested that he was preoccupied with psychotic symptoms. Delusions of reference and delusions of grandeur prevailed among the few statements he made. After initial stabilisation of his somatic condition the patient was referred to a psychiatric hospital.

Upon admission he presented without disturbance of consciousness; verbal contact was limited - he responded only to some questions with a delay (thought blocking) and he failed to make eye contact with examining physician. He was indifferent and apathetic. The patient seemed to be preoccupied with psychotic sensations. No thromboembolic risk factor was identified in his Padua Prediction Score based on the available information.
It should be noted that it was not possible to take comprehensive medical history because of the patient's mental condition. It was also not possible to contact patient's family to acquire more information.

The patient was initially mute at the ward. Passive negativism was observed. ECG performed upon admission revealed sinus tachycardia (impression: "Normogram. Regular sinus rhythm, 106 bpm"). Olanzapine, $10 \mathrm{mg}$, was initiated orally, hypokalaemia was continued to be compensated intravenously. A proton pump inhibitor was administered in line with post-discharge instructions from the internal medicine ward. Four-point restraints had to be used once. The olanzapine dose was increased to $20 \mathrm{mg}$ on two consecutive days. The patient's mental status partially improved after several days - he started to answer questions and make eye contact with the examining physician. He reported having auditory hallucinations and complained of physical malaise and recurrent abdominal pain. He was referred for an internal and surgical consultation, which revealed no significant abnormalities. ECG was performed at the time ("Normogram. Regular sinus rhythm, $70 \mathrm{bpm}$. Flattened negative T waves in lead II, III and aVF"). On the $9^{\text {th }}$ day of hospitalization the patient was supervised more extensively while taking his medicines and oral olanzapine was replaced with orally disintegrating tablets, because several tablets were found hidden in his room. His mental condition did not improve. On the contrary, it deteriorated: he reported exacerbated auditory hallucinations, refused to eat, did not cooperate and resisted nursing activities (passive and active negativism). The patient complained also of somatic symptoms: weakness, a burning sensation in his chest that worsened upon inhalation, abdominal pain, nausea; he vomited undigested food several times. Another internal consultation was referred there were no significant abnormalities and no indications for further diagnosis. On the $14^{\text {th }}$ day of hospitalization it was decided to switch olanzapine to haloperidol, $2.5 \mathrm{mg} /$ day, in intramuscular injections. The injections were administered to the patient at the same dose for 5 next days. D-dimer levels were assayed. They were elevated: $817 \mathrm{ng} /$ $\mathrm{ml}$ (ULN of up to $500 \mathrm{ng} / \mathrm{ml}$ ). The patient's mental condition continued to deteriorate despite the change in treatment. It was noted as follows: "The patient is lying in bed. He is not moving. He does not get up. He does not control his physiological needs"; "Muscle rigidity and negativity present while attempting to sit the patient down". Mutism, periodic freeze responses and non-physiological postures upon attempted activation were observed. On the $19^{\text {th }}$ day it was decided to re-initiate olanzapine, $20 \mathrm{mg} /$ day. Sudden cardiac arrest against a background of pulseless electrical activity (PEA) occurred on the $23^{\text {rd }}$ day of hospitalization. The patient died. Autopsy report stated: "Haemorrhagic pulmonary infarctions secondary to minor and moderate embolism. Pulmonary oedema". Pulmonary embolism was indicated as the direct cause of death. 
Pulmonary embolism - a considerable clinical challenge in psychiatry. Case reports

Zatorowość płucna - duży problem kliniczny w psychiatrii. Opisy przypadków

\section{Case 2}

A 36-year-old patient diagnosed with moderate intellectual disability and severe obsessive-compulsive disorder (OCD) was brought to the emergency room by an ambulance team with referral from a day mental health rehabilitation ward.

He was referred to the inpatient ward because of his mental status, which had been deteriorating for approximately two months. His family claimed that he was becoming more and more tense, irritable, and demanding. The patient wanted everyone do all activities for him and, when refused, responded with verbal aggression. During the day he was preoccupied with ritual gestures and activities. Stupor and mutism that lasted for several hours were observed before admission. Sometimes the patient showed active aggression towards people in his environment. He was treated with fluvoxamine $(200 \mathrm{mg} / \mathrm{d})$ and risperidone $(4.5 \mathrm{mg} / \mathrm{d})$. It was decided to modify pharmacological treatment because of lack of improvement and symptoms that may have suggested the onset of serotonin syndrome (increased sweating, tachycardia, limb muscle tremor, dilated pupils). The risperidone dose was gradually reduced and olanzapine, $10 \mathrm{mg} / \mathrm{d}$ was initiated at the same time. The patient was referred to a hospital because his condition failed to improve.

Upon admission, the patient presented without disturbance of consciousness. His autopsychic and allopsychic orientation corresponded to his intellectual disability. He was indifferent, and was psychomotor sluggish, tense, hypomimic. He presented with vegetative symptoms of anxiety. Sometimes he froze. He answered questions selectively, without any reference to them. The answers were delayed and each of them was given with stereotypical grimacing, blinking and hyperventilation. It was difficult to assess productive symptoms, however the patient denied having hallucinations. It was also difficult to perform physical examination because the patient did not cooperate. The following significant abnormalities were observed: severe obesity $(\mathrm{BMI}=31.95)$, ankle swelling and gynaecomastia. The patient refused to have ECG performed.

Medical records revealed that the patient had been repeatedly hospitalized in psychiatric units. He was 12 years old when he was hospitalized for the first time. At the time he presented with passive behaviour, apathy, and bizarre and maladjusted behaviour. During his last hospitalization at the inpatient ward two years previously, he was also diagnosed with OCD and schizophrenia in addition to intellectual disability. Catatonic stupor and refusal to eat and drink were observed for several years. Active negativism, muscle stiffness and exacerbating psychosis were reported. EEG revealed minor bilateral lesions in the temporal region.
Internal medicine history showed lipid metabolism disorders, impaired glucose tolerance and liver dysfunction (chronically elevated transaminase levels). The patient was diagnosed with arterial hypertension. He was treated with simvastatin, $20 \mathrm{mg} / \mathrm{d}$ and propranolol, $20 \mathrm{mg} / \mathrm{d}$. The risk of VTE was assessed upon admission using the Padua Prediction Score. He scored 1 point (for obesity with $\mathrm{BMI} \geq 30 \mathrm{~kg} / \mathrm{m}^{2}$ ).

The patient was diagnosed with organic catatonia during his ongoing hospitalization. Risperidone was discontinued on the ward. He was treated with fluvoxamine, $100 \mathrm{mg}$ in the morning and $200 \mathrm{mg}$ in the evening, and olanzapine, $10 \mathrm{mg}$ in the evening. On the ward he lay in bed most of the time. He needed diapers and assistance with everyday activities. He was sluggish, acted bizarrely and engaged in compulsions. On the $15^{\text {th }}$ day of hospitalization the patient reported that he felt worse. He claimed to have pneumonia and demanded antibiotic therapy. Examination revealed minor basal rales, a body temperature of $37.3^{\circ} \mathrm{C}$, and "dry, intermittent cough that seemed forced". His body temperature was normal during the internal medicine consultation conducted two days later. Vesicular murmur was normal. Infection was excluded. However, symptoms suggesting infection persisted over the following days. These observations were made on the $21^{\text {st }}$ day of hospitalization: "the patient has a productive cough and symptoms of upper respiratory congestion". On the $22^{\text {nd }}$ day of hospitalization the patient was found lying in bed without contact. He was not breathing and there was no heart rate. Resuscitation was started. Asystole was found after connecting a cardiac monitor. The patient died despite all the activities performed. Autopsy revealed embolism in the medium and small vessels, suggesting pulmonary embolism as the main cause of death.

\section{COMMENT}

The presented case reports show certain similarities. Firstly, both patients were young men (34 and 36 years old, respectively) with a long-term history of psychiatric treatment. They presented with catatonic symptoms and were treated with olanzapine. Both spent most of their time in bed and were not able to function independently, i.e. they required assistance and nursing with eating and drinking and diapering. In both cases the Padua Prediction Score was used to estimate thromboembolic risk on admission to the department and no indications for thromboprophylaxis were found. Using the example of the second case report, the need to reassess the risk of thromboembolic complications each time the patient's condition changes should be remembered. In the patient described, on admission the risk of VTE was assessed at 1 point using the Padua Prediction Score (for obesity with $\mathrm{BMI} \geq 30 \mathrm{~kg} / \mathrm{m}^{2}$ ). However, during hospitaliza- 
tion the patient remained in bed most of the time, which meant immobilization due to disability for $\geq 3$ days, assessed on the Padua Prediction Score with 3 additional points. On re-evaluation, the patient would receive 4 points, and a total score $\geq 4$ indicates high risk of VTE and is an indication for thromboprophylaxis [3]. Both men experienced sudden cardiac arrest and autopsy revealed $\mathrm{PE}$ as the main cause of death.

Pulmonary embolism is a common cause of death in patients with catatonia [4]. In $1995 \mathrm{McCall}$ et al. described two cases of sudden death in young female patients (aged 25 and 35) during catatonia and presented a literature review of 20 similar cases. PE was confirmed in autopsy in all patients. They died at least 2 weeks after they presented with catatonic symptoms. In most cases, death was sudden, without any prior symptoms [5].

A mortality review in psychiatric hospitals in Kentucky from 2002 to 2016 was published in 2017. Six out of 96 patients who died in this period were diagnosed with catatonia. All 6 patients died suddenly and autopsy revealed pulmonary embolism. The medical histories of all deceased patients was analysed in an attempt to decide whether any of those deaths were preventable. It was concluded that patient management modified at some stage would likely have saved 19 out of 96 deceased patients. Six patients diagnosed with pulmonary embolism with catatonia were in this group [6].

Increased risk of pulmonary embolism during episodes of catatonia is associated with several factors. Prolonged lack of physical activity slows down blood flow. Refusal to eat and drink, often associated with catatonia, may lead to dehydration, which in turn may increase blood coagulation. Productive symptoms can occur during episodes of catatonia. Psychosis and anxiety cause greater quantities of cortisol and catecholamines to be secreted, damaging vascular the endothelium and increasing coagulation $[7,8]$. It seems that symptoms of catatonia can activate all the elements of Virchow's triad, being the underlying mechanism of venous thromboembolism. Other signs of catatonia, such as mutism and negativism, make it impossible to communicate and cooperate with the patient, significantly hindering the diagnosis and treatment of pulmonary embolism and other conditions.

The issues discussed should be examined from another perspective - pulmonary embolism may induce delirium and manifest with symptoms that can be mistaken for catatonia, especially in patients with a history of this disorder. Hu and Chiu presented a case report of a 75-yearold man with a long history of schizophrenia and catatonic symptoms. Reappearance of stupor, mutism and refusal to eat were interpreted as a relapse of catatonia. The patient presented with dyspnoea, minor tachycardia (102 bpm) and subfebrile temperature. These symptoms were associated with exacerbated chronic obstructive pulmonary disease. After retrospective analysis it was concluded that symptoms that had been interpreted as relapsed catatonia resulted in fact from delirium caused by a developing pulmonary embolism [9]. It should be emphasised that it is necessary to precisely differentiate between catatonia and delirium, especially where hypoactivity is concerned [10].

Both of these patients displayed all the risk factors for thromboembolism during catatonic episode presented above: prolonged immobility, refusal to eat and drink (which may lead to dehydration), psychotic symptoms, anxiety, limited contact and cooperation resulting from mutism and negativism.

Additionally, consideration should be given to the effect of treatment used in a context of thromboembolic risk and possible symptoms that may have suggested developing pulmonary embolism.

In both men, olanzapine was the main antipsychotic drug used. There are many case reports in the literature suggesting an increased risk of thromboembolism in patients treated with this atypical antipsychotic. Maempel et al. described the case of a 27-year-old patient diagnosed with massive pulmonary embolism about 2 days after an olanzapine overdose [11]. Another case report is about a 28-year-old man who was treated for bipolar disorder. He developed a massive pulmonary embolism 4 months after initiation of olanzapine, $10 \mathrm{mg} / \mathrm{d}$. There were no other thromboembolic risk factors [12]. The following mechanisms of action of olanzapine that may increase thromboembolic risk are reported: reduced physical activity associated with sedation, weight gain and increased levels of prolactin, which has a pro-aggregating effect [13]. The affinity of olanzapine towards 5-HT2A receptors is also a possible mechanism of the prothrombotic effect of this antipsychotic, as it increases serotonin-induced platelet aggregation [14].

The main cause of death in both men was pulmonary embolism. PE is asymptomatic and is detected accidentally during other examinations or autopsy in about $50 \%$ of patients. In other patients symptoms are non-specific and may suggest many other disorders [15]. It should be noted that somatic complaints, associated with other causes, were reported in the first and second case. The first patient complained of weakness, a burning sensation in his chest that worsened upon inhalation, abdominal pain, nausea, and vomiting with undigested food several times. These complaints were interpreted, for example, as sequelae of recent bleeding from the upper gastrointestinal tract. The second patient reported symptoms of infection and claimed to have pneumonia. He presented with cough and a subfebrile temperature, but these symptoms were not persistent. Essential physical examination did not raise any concern. But there are no symptoms that are pathognomonic for PE. This condition is non-specific and may resemble many other disorders, which is why it should always be taken into account during differential 
diagnosis, even in patients without obvious thromboembolic risk factors. Greater caution seems to be of particular importance in patients with catatonia.

It should be emphasized that the assessment of the risk of thromboembolism according to the Padua Prediction
Score should be used when a patient is admitted to a department, and each time the patient's condition changes or additional information about them is obtained, which may change their score.

\section{Conflict of interest/Konflikt interesu}

Absent./Nie występuje.

Financial support/Finansowanie

Absent./Nie występuje.

\section{References/Piśmiennictwo}

1. Konstantinides SV, Meyer G, Becattini C, Bueno H, Geersing GJ, Harjola VP, et al. 2019 ESC Guidelines for the diagnosis and management of acute pulmonary embolism developed in collaboration with the European Respiratory Society (ERS). Eur Heart J 2020; 41: 543-603.

2. Takeshima M, Ishikawa H, Shimizu K, Kanbayashi T, Shimizu T. Incidence of venous thromboembolism in psychiatric inpatients: a chart review. Neuropsychiatr Dis Treat 2018; 14: 1363-1370.

3. Tomkowski W, Kuca P, Urbanek T, Chmielewski D, Krasiński Z, Pruszczyk P, et al. Venous thromboembolism recommendations on the prevention, diagnostic approach, and management. The Polish Consensus Statement 2017. Acta Angiol 2017; 2: 35-71.

4. Levenson JL. Medyczne aspekty katatonii. Psychiatria po Dyplomie 2009; 6: 89-93.

5. McCall WV, Mann SC, Shelp FE, Caroff SN. Fatal pulmonary embolism in the catatonic syndrome: two case reports and a literature review. J Clin Psychiatry 1995; 56: 21-25.

6. Puentes R, Brenzel A, de Leon J. Pulmonary embolism during stuporous episodes of catatonia was found to be the most frequent cause of preventable death according to a state mortality review: 6 deaths in 15 years. Clin Schizophr Relat Psychoses 2017. DOI: 10.3371/CSRP.RPAB.071317.

7. Bloodworth RC. The use of the dexamethasone suppression testin the differential diagnosis of catatonic stupor. Int J Psychiatry Med 1983; 12: 93-101.

8. Wheeler AH, Ziegler MG, Insel PA, Motulsky HJ. Episodic catatonia, hypertension, and tachycardia: elevated plasma catecholamines. Neurology 1985; 35: 1053-1055.

9. Hu HCh, Chiu NM. Delayed diagnosis in an elderly schizophrenic patient with catatonic state and pulmonary embolism. International Journal of Gerontology 2013; 7: 183-185.

10. Stagno D, Gibson C, Breitbart W. The delirium subtypes: a review of prevalence, phenomenology, pathophysiology, and treatment response. Palliat Support Care 2004; 2: 171-179.

11. Maempel JFZ, Darmanin G, Naeem K, Patel M. Olanzapine and pulmonary embolism, a rare association: a case report. Cases J 2010; 3: 36.

12. Toringhibel M, Adam T, Arghir OC, Gima E. Acute massive pulmonary embolism associated with olanzapine therapy and no significant personal history in a young male - case report and literature review. Pneumologia 2011; 60: 82-84.

13. Manu P, Hohman Ch, Barrecchia JF, Shulman M. Pulmonary embolism. In: Manu P, Flanagan RJ, Ronaldson KJ (eds.). Life-Threatening Effects of Antipsychotic Drugs. Elsevier; 2016, p. 59-79.

14. Borras L, Eytan A, Timary de P, Constant EL, Huguelet P, Hermans C. Pulmonary thromboembolism associated with olanzapine and risperidone. J Emerg Med 2007; 35: 159-161.

15. Wiśniewska J, Zieliński T. Profilaktyka zakrzepowo-zatorowa a uaktualnione wytyczne NICE z 2018 roku. Medycyna po Dyplomie 2018; 11. 